\title{
LA ORGANIZACION DE PRODUCTORES FAMILIARES EN LAS FERIAS FRANCAS DE LA PROVINCIA DE CÓRDOBA
}

\author{
Ferrer, G. ${ }^{1 ;}$ BARrientos, M. ${ }^{1} \&$ SAAL, $G .{ }^{1}$
}

\begin{abstract}
RESUMEN
El objetivo de este artículo es comprender los procesos organizativos de 12 ferias francas de la provincia de Córdoba. Para ello se realizaron entrevistas a actores clave durante los años 2014 y 2015. Si bien las ferias francas son valoradas inicialmente como una solución apropiada tanto para los consumidores conscientes, como para los productores familiares que buscan una alternativa de comercialización más sustentable, el análisis revela que las mismas son un campo social tensionado por relaciones de colaboración/competencia entre diversos actores que interactúan en el territorio. Los resultados permiten identificar dos tendencias en disputa en la mayoría de los feriantes: i) la asamblearia, que sostiene una posición individualista y confía en la regulación del proceso que realizan los consumidores y; ii) la formalizante, que propicia la organización en comisiones internas que acuerden normas para el comportamiento de los feriantes.
\end{abstract}

Palabras clave: ferias de productores, productores familiares, economía social.

\begin{abstract}
The organization of family producers in the free fairs of the province of Cordoba.

The purpose of the present article is to understand the organizational processes of 12 tax free fairs trades in the province of Cordoba. To this end, key stakeholders were interviewed during the years 2014 and 2015. Tax free fairs trades are initially valued as an appropriate solution for both conscious consumers and family farmers seeking a more sustainable marketing alternative. Nevertheless the analysis reveals that they are a social arena stressed by relations of collaboration / competition between diverse actors that interact in the territory. The results make it possible to identify two
\end{abstract}

1.- Departamento de Desarrollo Rural. Facultad de Ciencias Agropecuarias (UNC). Ing. Agr. Félix Aldo Marrone 746. Ciudad Universitaria. CC 509. (5000) Córdoba. Tel.: (0351) 4334103. Email: guillermoferre@gmail.com Manuscrito recibido el 28 de junio de 2017 y aceptado para su publicación el 19 de septiembre de 2017. 


\section{G. Ferrer et al.}

trends in dispute in the majority of the participants: i) the assembly, who holds an individualistic position and trusts in the regulation of the process that can be made by consumers; ii) the formalizer, which facilitates the organization in internal commissions that agree norms for the behavior of the members.

Key words: Farmers market, famiily farming, social economy.

\section{INTRODUCCION}

Las ferias francas constituyen un fenómeno relativamente reciente en Argentina. Su origen se vincula con la experiencia realizada en Oberá Misiones, ha mediado de la década del noventa, como una forma de resistencia y búsqueda de alternativa de las familias para sobrevivir en el campo, dado el contexto de desplome de los precios de los cultivos industriales tales como yerba y té. Los productores familiares expandieron las huertas de autoconsumo de sus predios y se organizaron para vender esos productos en las ciudades cercanas (1)

Una Feria Franca de productores es un espacio de comercialización organizado de los productores familiares que genera un impacto socio- económico y cultural en las unidades de producción, en el núcleo de las familias feriantes y en las localidades donde se realizan (2). Se diferencian de las ferias francas tradicionales porque los puesteros son, a su vez, los productores y pueden responder por la calidad de sus productos. Algunas ferias, dando especial énfasis a la calidad, se auto imponen comercializar sólo productos agroecológicos, lo que implica que no han sido tratados con agro tóxicos y que provienen de unidades de producción familiares locales.
Según un relevamiento realizado por Golsberg y Dumrauf (9), en el año 2010 existían 144 ferias francas en todo el país, ubicadas con una clara preponderancia en la zona mesopotámica, donde se destaca la provincia de Misiones. En un estudio realizado para la provincia de Córdoba (3) se relevaron 12 ferias francas con una frecuencia por lo menos mensual. Destacando que la zona serrana cordobesa es el territorio donde se agrupan en mayor proporción.

Las ferias francas de productos agroecológicos constituirían una buena solución, tanto a los consumidores conscientes, como a los productores familiares que buscan una alternativa de comercialización sustentable. Pero la constitución de las ferias no parece ser algo sencillo. Por el contrario, podemos afirmar, que la conformación de las ferias exige un esfuerzo organizativo importante por parte de actores variados del territorio, ya que interactúan en un campo tensionado por relaciones de colaboración/competencia.

En el trabajo de Ferrer y otros arriba citado, se establecieron dos posiciones en disputa ante los procesos organizativos en la mayoría de las ferias: la asamblearia, que privilegia una posición individualista de los feriantes y confía en la selección/ regulación que pueden hacer los compradores y la formalizante, que propicia la organización en comisiones internas y reglar el comportamiento de los feriantes. 